\title{
The Gray Zone in Poland - Phenomenon, Conditions and Causes, Multifaceted Consequences
}

\author{
Piotr Możyłowski ${ }^{1}$, Katarzyna Kalinowska ${ }^{2}$
}

\begin{abstract}
:
Factor in the competitiveness of businesses and other taxpayers and the smooth running of this development is the legal security of doing business. It is expressed inter alia the requirement of maintaining the stability and consistency of assessment. Violations of these rules, especially now, in the era of economic downturn will cause loss of public confidence in the state. The consequence of the lack of acceptance by the taxpayer of the tax burden and the social- business' doctrine is to try to tax evasion and transfer activities to the informal economy. The increase in the shadow economy will not only transmission ratio on public finances, but also on the socio-economic situation. Budget revenue will decrease because some entities eliminate economic activity thus "pass" for the maintenance of the State, or move their activities to the informal economy.
\end{abstract}

Key Words: tax system, grey zone, tax barriers, economic activity, financial crisis

UDC indices: $336,336.1,336.2$

${ }^{1}[\ldots]$
$2 \ldots]$ 


\section{Introduction}

Regardless of the emotional relationship of the citizens to the state as their homeland more realistic attitude towards the state is visible which is a kind of meter which shows confidence of citizens in the state including the tax authorities [Kostecki, p. 539]. For these reasons, the principle of shaping by the authorities, public confidence was raised to the rank of the basic principles of a democratic state of law. The citizens` trust turns directly into the positive assessment of the functioning of the state, while the lack of trust makes clear their negative assessment. In addition, as noted by A. Kostecki, you should be aware that the democratic state with lack of citizens' trust cannot function properly using its structures and institutions, sometimes losing the characteristics of a democratic state of law. Referring to the construction of the tax system, it should be noted that the feature of a democratic state is to build the confidence of citizens to the state. This confidence can be achieved through the creation of tax rules characterized by considerable stability. As a specific violation of the principle of trust of citizens (taxpayers) to the tax authorities, it should be considered when drafting rules which do not comply with the principle of lex retro non agit. Similarly, the principle of trust excludes the application of the law using the rule in dubio pro fisco if not quite precisely formulated or insufficiently clear or wrong interpreted.

The consequence of the lack of acceptance by taxpayers of the tax burden or social doctrine - is try to tax evasion. Going to the gray zone is not a new phenomenon that appeared suddenly and it happened in the transition of the Polish economy. Although fiscal services, as well as representatives of science make efforts to determine the scale of tax evasion failed so far to create effective counter.

In this work the author attempted to show the causes of the shadow economy in Poland. He analyzed and identified the main reasons for the relocation of the informal economy. The author based on his professional experience, and generally available research, created a directory causes of the shadow economy. Such representation of the factors conducive to the development of the shadow economy, it is the author's important, because this action politicians and many economists have led to this state of affairs. It is also important now, when facing the global economic crisis in Europe and the world.

\section{The rate of the gray zone in Poland}

Lack of acceptance for the tax burden or even the tax system will manifest itself in the relocation of the informal economy. Economists take various attempts to estimate the size of this indicator. In Poland, apart from the Central Statistical Office, some centers offers research in this field. The tax authorities tried to 
determine this number as well. Research conducted by the Tax Officers in 1992 [Komór, 61] has shown that one in four has cheated the state, and almost $75 \%$ of the companies were accused of "depletion tax." At this point it should be noticed that the investigation on the size of the informal economy are inconsistent with each other ${ }^{3}$. For example, the share of the shadow economy in Polish GDP in 2003 was 13.2\%, according to the CSO and 28.9\%, according to F. Schneider [Sowiński, p. 84]. To give an idea of the enormity of the problem the Fig. 1 shows the size of the grey zone in Poland and in the EU in 2012.

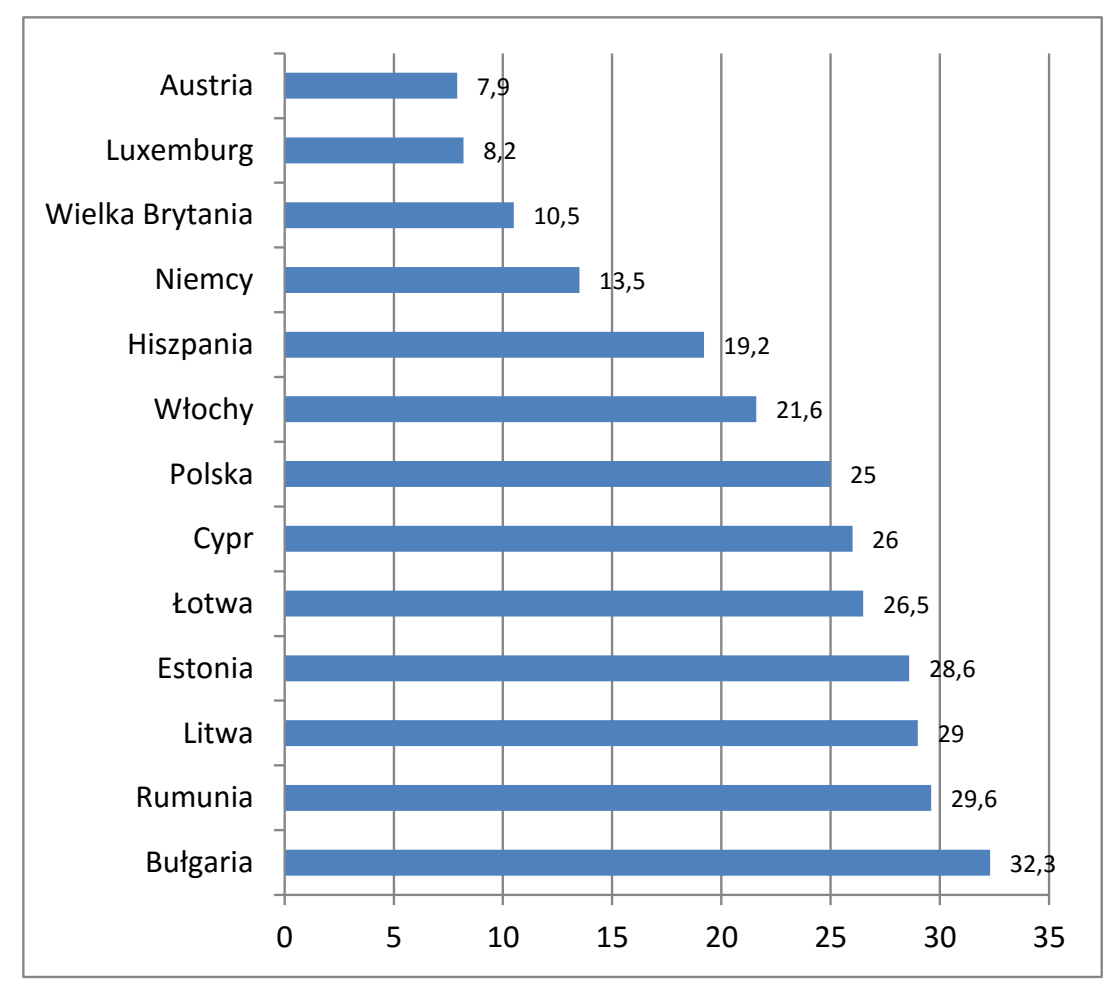

Figure 1. The grey zone range in Poland in comparison to the other EU countries in 2012 [1]

This data make it possible to observe a relationship. The rate of the gray zone in the new EU countries is higher than in the countries of the "old Europe". Looking at the map of Europe we can observe a relationship. We can observe that the gray zone rate grows when we follow from west to east Europe. A similar relationship exists when we look from the north to the south of the continent. In this ranking, Poland is quite high - in the negative sense. The data presented in the graph indicate the fact that the

\footnotetext{
${ }^{3}$ It results from different counting method.
} 
indicators published by prof. Schneider are much higher than the estimates published by the CSO. Cautious in their estimates of the report authors were even signed by the European Commission in 2004. According to their calculations in Poland the share of the grey zone in GDP was more than twice smaller than that indicated by the professor. Schneider. Still other economists indicate data from the Centre for Socio - Economic, who point out that the business hidden from the tax authorities can be two times greater [Newspaper Small and Medium Enterprises ", p. 4].

When analyzing the rate of the grey zone in Poland, the existence of the tax gap should be mentioned. This phenomenon is called the difference between what the taxpayer should pay, and what is actually paid to the state budget. It can therefore be assumed that the state budget loses money consistently year by year. Graph 1 shows the tax gap in VAT in the years 2006-2012.

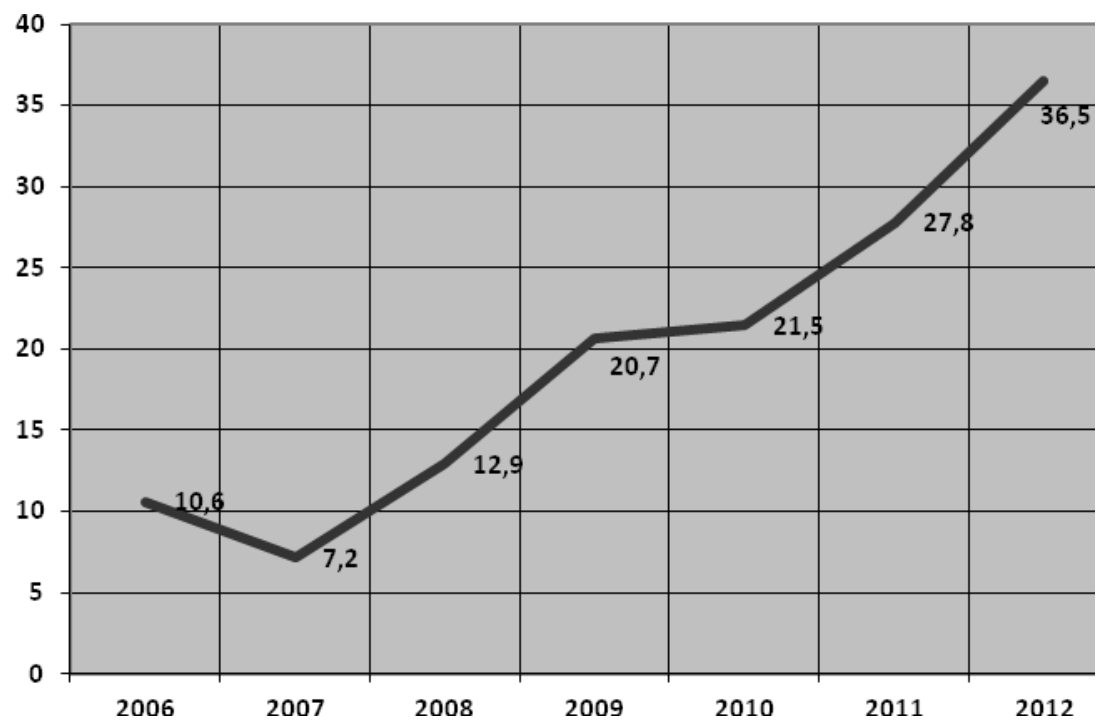

Graph 1. The VAT gap in Poland between 2006 - 2012 in billions PLN [Popiołek]

As clearly seen in the graph the tax gap in Poland is growing. Only in the years 2010 - 2012 the gap has increased by 15 billion PLN. This amount, according to some experts, includes fraud of value added tax (VAT). Unfortunately, neither the tax authorities nor law enforcement agencies have not found a solution to this problem yet. And it is not just about lowering the tax base by legally operating businesses. The bigger problem for the tax administration is called "disappearing taxpayer" as well as the "effect of carousel".

\section{Factors affecting the gray zone in Poland}


The causes of the shadow economy in large part have been identified and defined. In Poland such factors as significant burden on income taxes and value added tax and social security contributions have been identified as shown in Fig. 2.

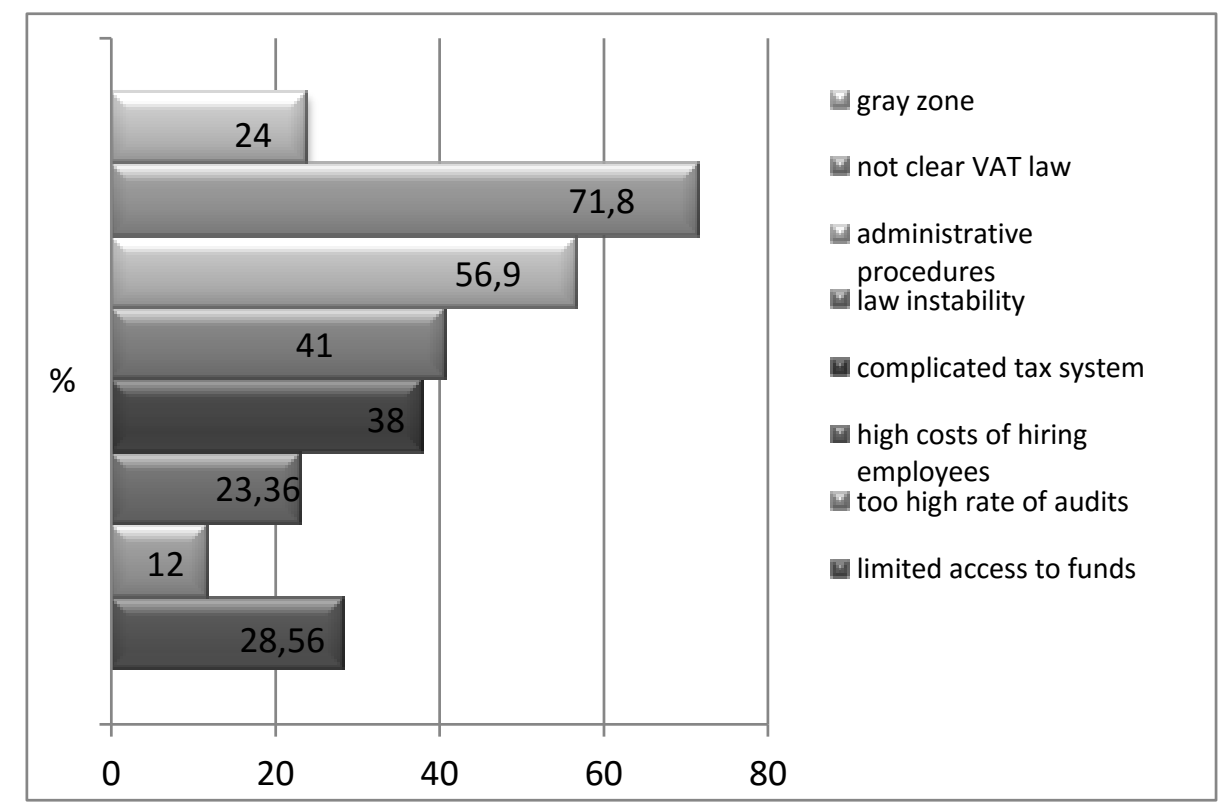

Figure 2. Administrative barriers when holding business [2]

The identified factors have most impact on the business sector of the SME group. In the surroundings you can see a lot of hostile phenomena such as negative behavior of people and institutions and offices or preserved contractors who do not regulate their obligations. These reasons may include frequently changing laws and their complexity as well. It will also be inefficient operation of the legislator, which in the opinion of various social groups will be considered as an interference with the principle of universality and stability of taxation ${ }^{4}$.

Among the barriers to economic activity, and thus tending to move to the informal economy, a key position is the poor quality of tax law (concerning direct and indirect taxes) and the costs of the application of tax law. In the small and mediumsized enterprises in Poland, the existing tax system and the amount of taxes, create

\footnotetext{
${ }^{4}$ In Poland, from time to time introduced all sorts of "amnesty - tax and insurance." In recent times, ie., In November 2012., Enacted provisions regarding the possibility of redemption of social security contributions of people who did not pay them for 10 years (from 1999 to 2009). This means that taxpayers fairly prosperous again were somehow "cheated". Once again, the Polish politicians showed that not really need to be to you "fair".
} 
major barriers to the development of SMEs and affect their economic situation. [Chądrzyński, p. 130] Worrying is the fact that entrepreneurs are less afraid of competition from the gray economy than applicable taxes and a number of their changes. Additionally the research conducted by the Tax Care and the Idea Bank indicate that in addition to limited access to business finance administrative the biggest barrier is just vague and complicated tax regulations. It was pointed by more than $24 \%$ of the surveyed entrepreneurs. The author in this place would like to draw attention to the fact that the tax laws - and not only - are created in large part by the politicians, who do not necessarily have to know them. Of course laws are often prepared by a team of professionals or scientists, however, they obtain the final shape of legislation in parliament. Unfortunately, lack of professionalism and knowledge has led to such a situation where part of the rules is poor quality as can be seen in Fig. 3.

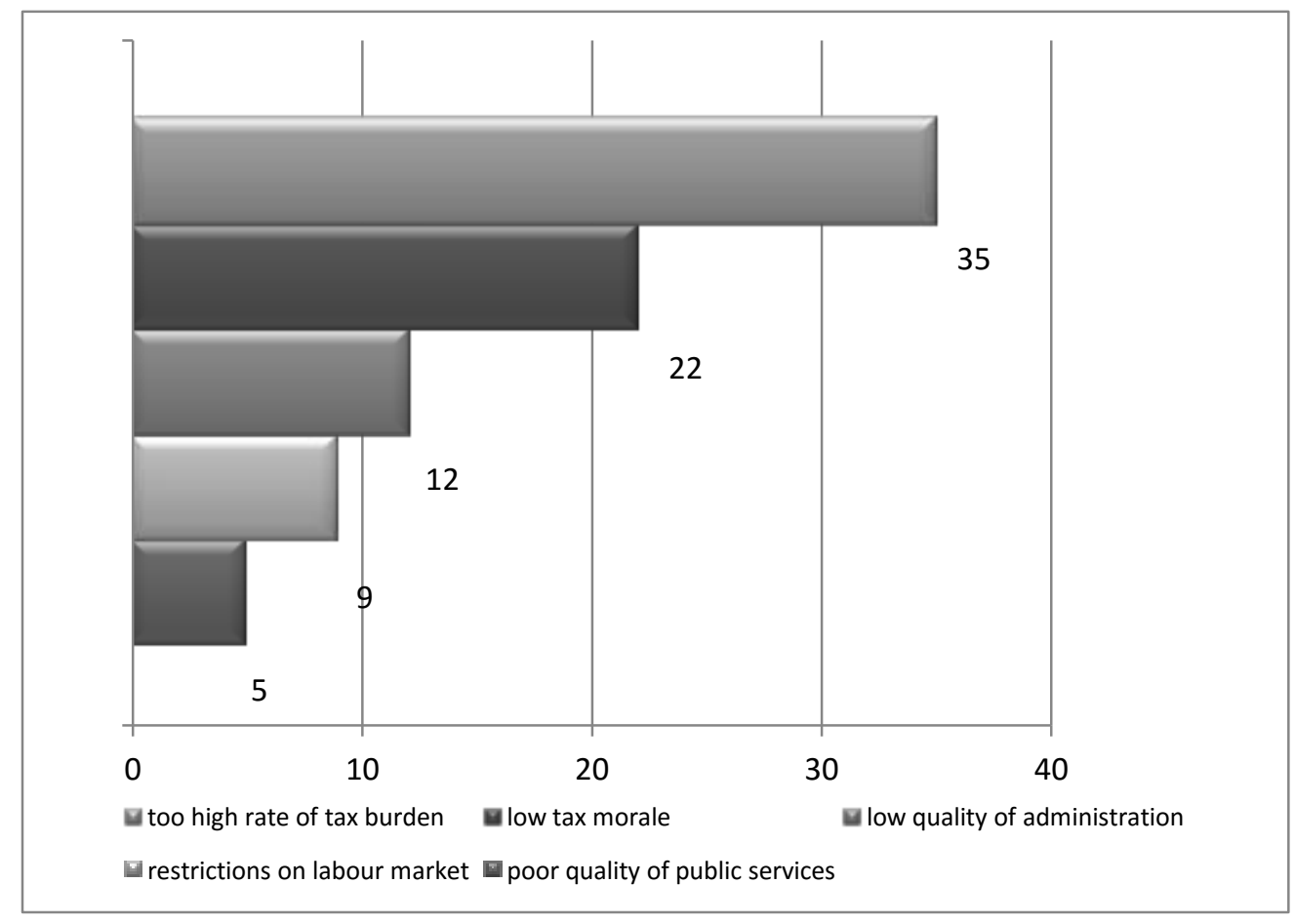

Figure 3. Reasons to move business to the gray zone in Poland [3]

Contributions in Poland in relation to the taxes are quite high which significantly increases the cost of labor. The labor demand weakens and probably contributes to the high rate of unemployment. At this point we can look at the balance of income and expenditure of Polish national funds which provide basic social (ZUS and KRUS) whose total sum of deficits is counted in billions of dollars. Unfortunately this shortfall will have to be covered by transfers from the state budget or from 
direct taxes, indirect taxes and loans. Social security contributions are the primary factor in labor costs. [Możyłowski, p. 199] The proposed reduction in premiums, what actually happened in the years 2007-2008, by reducing pension contributions would increase the supply of labor, however, this decreased the funds available for the payment. This dilemma occurs very sharply in Poland and has not been resolved so far.

Issues related to social security contributions and the "gray zone" we can find in the GUS research which deals with this problem in the labor market. It is difficult to estimate the size of working in the "gray zone" but you can look for the answers why all this is happening at all. Research conducted by the Central Statistical Office in 1995 show that the number of people admitting to work in the informal economy decreases $^{5}$ : in 1995. - 2.199 thousand, 1998 - 1431 thousand, $2004-1,317$ thousand, 2009 - 785 thousand people, which accounted for $4.6 \%$ of the total working population. [Work, p. 15] In a study conducted by the Central Statistical Office the cause of undeclared work in Poland in terms of their "validity" of respondents was determined. Fig. 4 identifies the causes of undeclared work.

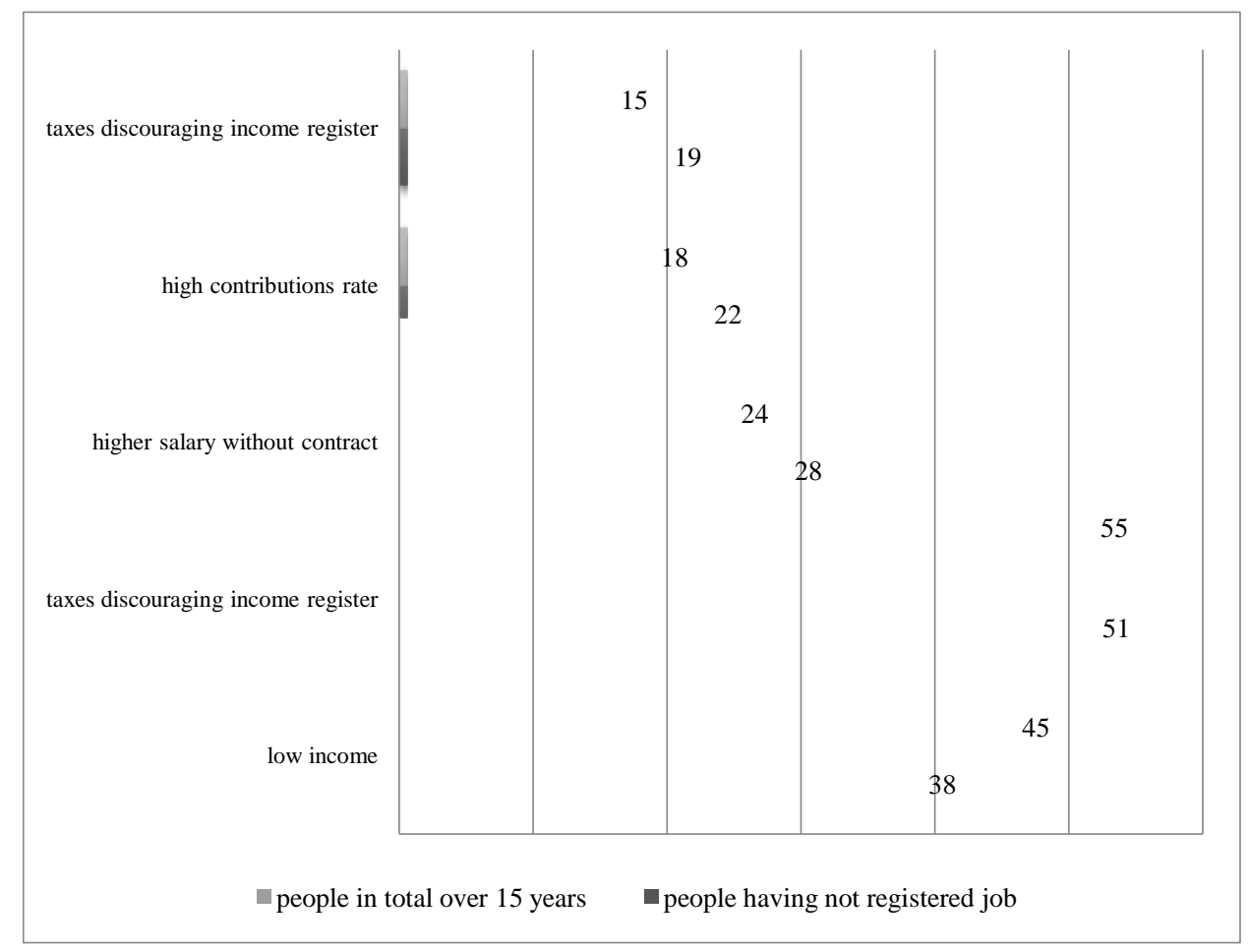

Figure 4. Causes of undeclared work [4]

\footnotetext{
${ }^{5}$ It does not mean that the number decreased
} 
People make undeclared work for many reasons but there is a kind of hierarchy of motives which they direct. The largest number of respondents pointed to the cause like lack of job opportunities and insufficient income. Further reasons having a significant impact on working in the "gray zone" were offered higher wages by the employer without a contract and the high social security contributions as well as taxes that discourage the recording of the income.

At this point we should emphasize the fact that the burden of premiums are also high in other EU countries. In the last decade, workers load grew mainly where clearly raised the level of rates (the Netherlands, France, Italy). The burden of employers fell the most when lowering rates (Finland, Ireland). The exception was the United Kingdom, where in the framework of reducing the burden of social insurance premiums abolished completely for the employees, keeping only the burden of employers. Low premiums for employees persist besides Ireland (6\% of gross salary) in Scandinavia (6.35\% in Finland, 7\% in Sweden, 9\% in Denmark). The burden fell appreciably on contributions of workers in Greece (from 27.96\% in 1996 to $16.22 \%$ in 2005). However, this was accomplished at the expense of an increase in premiums for employers.

However in the Czech Republic, Poland, Slovenia, Slovakia and Hungary social security contributions are high and generally do not deviate from the average level of contributions in the EU-15. Contributions are significantly lower in Cyprus and Malta. They are also relatively low in the Baltic countries (between $33-34.5 \%$ of gross salary) with the dominant proportion (33.5\% in Estonia, 24\% in Latvia) covered by employer.

Analysis of the data provided in the study related to the transition to the informal economy can offer the basis of factors conducive to the development of this particular sphere of economic life. Fig. 5 shows the factors conducive to the development of the shadow economy in Poland. In the proposed division of the factors associated with the risk of such activities, lack of guilt or objective evidence of such activities.

Table 1. Factors conductive to the gray zone development in Poland [5]

\begin{tabular}{|c|c|c|}
\hline $\begin{array}{c}\text { Factors known as } \\
\text { positive by tax payers }\end{array}$ & Lack of guilt & Low risk belief \\
\hline $\begin{array}{l}\text { - complicated tax } \\
\text { system } \\
\text { - bad labour law } \\
\text { - economic crisis } \\
\text { - benefits of not paying } \\
\text { taxes }\end{array}$ & $\begin{array}{l}\text { - negative opinion of state } \\
\text { activity } \\
\text { - negative opinion of existing } \\
\text { taxes } \\
-\quad \text { tradition and social } \\
\text { acquiscence } \\
\text { - low awarness of rights and }\end{array}$ & $\begin{array}{l}\text { - low probability of } \\
\text { detection of tax crime } \\
\text { - low effectiveness of tax } \\
\text { offices } \\
\text { - low difference between } \\
\text { benefits and punishment }\end{array}$ \\
\hline
\end{tabular}




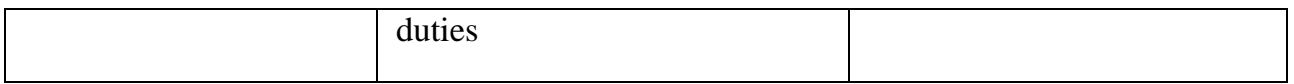

The above-mentioned factors clearly point to the fact that people investing their activities in the informal sector are not afraid of it. They are convinced of the low efficiency of treasury services as well as the low penalty for any tax offense detected. The increase in the gray zone also consist of factors such as the economic downturn, the increase in the minimum wage and well criticized by part of the society and economists, the increase in pension contributions from 2012.

\section{Advantages and disadvantages of the existence of the shadow economy}

The gray zone was, is and will still be an integral part of the economic environment. The problem is the different perception of the phenomenon. Some will criticize it others will mention a salutary effect on the finances of the state. Yet another problem of the existence of a gray area shows the B. Mróz. He states that the drafting of the full balance of the economic and social costs and benefits of the occurrence of different forms of undeclared economic activity is not an easy task. [Mróz, pp. 90-91]. It shows the fact that it distorts the rules of fair competition, resulting in a reduced tax revenues to the state budget, and prevent the financing of major social programs. However, he believes that it is forgotten the fact that informal economic activity has its good side: neutralizes the effects of unemployment, provide additional income to poorer households, and allows us to satisfy basic needs of life of many consumers. For confirmation of his case shows the balance of benefits and costs of the shadow economy from the perspective of macroeconomic and consumer (Tab. 2).

Table 2. The benefits and costs of the occurrence of the shadow economy from the perspective of macroeconomic and consumer [6]

\begin{tabular}{|l|l|}
\hline \multicolumn{1}{|c|}{ Costs and losses } & \multicolumn{1}{c|}{ Benefits } \\
\hline $\begin{array}{l}\text { 1. Avoiding paying taxes (PIT, CIT, VAT) } \\
\text { depletes the state budget revenues and } \\
\text { reduces the possibility of financing the } \\
\text { areas important for the smooth functioning } \\
\text { of a modern state (education, health) }\end{array}$ & $\begin{array}{l}\text { 1. Loss due to unpaid taxes are offset by } \\
\text { the fact that more than 2 / 3 income earned } \\
\text { in the shadow economy is spent in the } \\
\text { official economy thereby increasing } \\
\text { consumer demand, economic growth and } \\
\text { contributes to an increase in revenues from } \\
\text { indirect taxes included in the prices of } \\
\text { goods and services purchased in the formal } \\
\text { sector }\end{array}$ \\
\hline $\begin{array}{l}\text { 2. Evasion of social security contributions } \\
\text { reduces the income of Social Security } \\
\text { prevents the development of the working } \\
\text { part of the pension which in turn will lead }\end{array}$ & $\begin{array}{l}\text { 2. It is estimated that the income received } \\
\text { by those working in the informal sector to } \\
\text { increase their standard of living at least } 1 / 5 \\
\text { (depending on the share of income earned }\end{array}$ \\
\hline
\end{tabular}




\begin{tabular}{|l|l|}
\hline $\begin{array}{l}\text { to the need for the provision of social } \\
\text { assistance to those persons publicly funded }\end{array}$ & $\begin{array}{l}\text { in the informal economy in general revenue } \\
\text { of the population) }\end{array}$ \\
\hline $\begin{array}{l}\text { 3. Evasion of social security contributions } \\
\text { and sickness lowers the efficiency of the } \\
\text { public health care }\end{array}$ & $\begin{array}{l}\text { 3. The cost of labor in the informal sector } \\
\text { are much lower than in the formal sector, } \\
\text { which allows the use of the product } \\
\text { structure - the informal sector service-to-do } \\
\text { people worse and increases the level of } \\
\text { their life }\end{array}$ \\
\hline $\begin{array}{l}\text { 4. Evasion accident insurance premiums } \\
\text { would cause lack of funds }\end{array}$ & $\begin{array}{l}\text { 4. Income left in the gray area of the unpaid } \\
\text { taxes is better than would be used in the } \\
\text { public finance sector }\end{array}$ \\
\hline $\begin{array}{l}\text { 5. Evasion labour fund contribution limits } \\
\text { the ability to pay benefits to the } \\
\text { unemployed and their professional } \\
\text { activation }\end{array}$ & $\begin{array}{l}\text { 5. Gray zone allows activation of marginal } \\
\text { labor, creating employment opportunities } \\
\text { for people with lower qualifications and for } \\
\text { those who cannot or do not want to work } \\
\text { full-time work }\end{array}$ \\
\hline $\begin{array}{l}\text { 6. The erosion of business ethics, creating } \\
\text { conditions of unfair competition by } \\
\text { companies that do not pay taxes, social } \\
\text { security contributions and do not respect } \\
\text { the provisions of the Labour Code }\end{array}$ & $\begin{array}{l}\text { 6. Undeclared work in the informal } \\
\text { economy creates the unemployed a chance } \\
\text { to avoid the stigma of social exclusion and } \\
\text { gives you the ability to maintain } \\
\text { professional skills. }\end{array}$ \\
\hline
\end{tabular}

\section{Summary}

Unfortunately the informal economy cannot be completely eliminated. That is because there will always be people who will not be willing to pay even the lowest tax. The author's experience points to the fact that the majority of people in Poland decides to move to the shadow economy in a conscious way. With high probability it can be said that this is a deliberate and targeted action to avoid paying tax and other public contributions. Unfortunately it is not possible to restrict or eliminating the gray zone by means of various administrative measures. In addition, such a situation will intensify the actions of politicians, which will be evaluated in a reprehensible way by taxpayers.

In the current circumstances it is and should be continued to implement already existing solutions for the tax system consisting of:

$>$ modernizing and simplifying the tax system;

$>$ reduction in the basic rate of tax on goods and services, rather than raising it as did the Government since 2011; 
$>$ broadening the tax base in a manner consistent with the principles of taxation (ie tax to cover new groups of taxpayers), and not the principle that increasing the burden for those who are already paying;

$>$ tax harmonization with European Union regulations;

$>$ ordering statutory provisions in respect of income tax expenses constituting deductible costs;

$>$ cease its policy of limiting the deduction of input VAT on the growing number of goods and services;

$>$ elimination of changes in tax laws during the fiscal year (as is currently the case where the bill amends several times a year);

$>$ introducing at least 6 months "vacatio legis" for tax changes

Stabilize the tax laws and possibility to become familiar with changes may not eliminate the informal economy but it should help to narrow the gap. This legislation largely affect escape into the informal sector which should be forced to think of Polish politicians, in particular, the Minister of Finance who is responsible for fiscal policy. He must understand that the creation of further tax barriers consequently increases the fiscal burden and it not only not increase the tax revenue of the state budget. On the contrary revenue is expected to be reduced because some entrepreneurs entities or eliminate economic activity and thus go to get money from the state, or transfer its activities to the informal economy. This was the situation we have in Poland.

\section{Notes}

[1] F. Schnaider, Size and Development of the shadow economy of 31 European and 5 other OECD Countries from 2003 to 2012: Some New Facts

[2] Badanie nad przedsiębiorstwem, BCC i Instytut GFK, Monitor Firm GFK Polonia, Warszawa 2011; DGP, 07.10.2011

[3] Szara strefa, błogosławieństwo kapitalizmu, Dziennik Gazety Prawnej, 13 - 15 stycznia 2012, nr 9 (3147)

[4] Praca nierejestrowana w Polsce w 2010 roku, GUS, Warszawa 2011, s. 16

[5] opracowanie własne

[6] B. Mróz, Rola szarej strefy w zaspakajaniu potrzeb polskich konsumentów w warunkach kryzysu gospodarczego [ w:] Reakcje polskiego konsumenta na kryzys gospodarczy, T. Słaby (red.), Wydawnictwo SGH, Warszawa 2009, s. 91

\section{References:}

Literature:

I. Bolkowiak, Polski system podatkowy w okresie transformacji ustrojowej (lata 1989-1999). Instytut Finansów, Warszawa 1998

M. Chądrzyński, Gtówne bariery rozwoju $i$ funkcjonowania matych $i$ średnich przedsiębiorstw na obszarach wiejskich województwa łódzkiego [w:] Rola przedsiębiorczości w aktywizacji gospodarczej (red.) Z. Zioło i T. Rachwał, Kraków Warszawa, Wydawnictwo Nowa Era 2007 
R. Gwiazdowski, Podatek progresywny i proporcjonalny. Doktrynalne przestanki, praktyczne konsekwencje, Wydawnictwo Uniwersytetu Warszawskiego, Warszawa 2007

C. Kosikowski, Podatki. Problem władzy i podatników. LexisNexis, Warszawa 2007

A. Kostecki, Charakter i rodzaje instytucji ochrony praw podatnika w polskim ogólnym prawie podatkowym [w:] Główne wyzwania i problemy systemu finansów publicznych, red. J. Głuchowski, A. Pomorska, J. Szołno-Koguc, Wydawnictwo KUL, Lublin 2009

A. Krajewska, Podatki w Unii Europejskiej, Polskie Wydawnictwo Ekonomiczne, Warszawa 2010

P. Możyłowski, Składki na ubezpieczenia społeczne jako czynnik kształtujacy pozapłacowe koszty pracy [w:] Prawo pracy czynnikiem skutecznego kierowania ludźmi, pod red. A. Nowaka, Wydawnictwo WSNSiT, Radom 2013, s. 199 i n.

Władza fiskalna a reakcje podatników na obciązenia podatkowe. Praca zbiorowa pod redakcją Teresy Famulskiej i Krystyny Znanieckiej. Prace naukowe Akademii Ekonomicznej im. K. Adamieckiego w Katowicach. Katowice 2001

Articles:

S. Bukowski, Funkcje podatków w okresie transformacji w Polsce [w:] S. Flejterski, A. Szewczyk ( red.), Finanse i bankowość - dźwignie wzrostu gospodarczego, (materiały konferencyjne - Zjazd Katedr Bankowości i Finansów),Uniwersytet Szczeciński, Międzyzdroje, wrzesień 1998

Czarna Lista Barier dla rozwoju przedsiębiorczości 2013, Lewiatan, Warszawa, Maj 2013

W. Komór, Wykiwany fiskus, Gazeta Wyborcza 1993, nr 61

T. Chrościcki, Szara strefa w polskiej gospodarce na tle innych krajów, Nowe Życie Gospodarcze, 16.05.2007r

Gazeta Malych i Średnich Przedsiębiorstw”, nr 2/2004

R. Gwiazdowski, Absurdalność istniejacego systemu podatkowego, „Interes publiczny”, CAS, Warszawa, Czerwiec 1999

J. Kowalski, Szara strefa: produkcja i ustugi za 133 mld złotych, „Gazeta Prawna” 3 luty 2006, nr 25

A. Popiołek, Na oszustach VAT tracimy 36 mld zł. Eksperci wyceniają straty, Mój Biznes, gazeta.pl, 15.01.2014

R. Sowiński, Skutki zjawiska uchylania się od opodatkowania - przeglad problematyki [w:] Podatkowe i niepodatkowe źródła finansowania zadań publicznych, J. Głuchowski, A. Pomorska, J. Szołno-Koguc (red.), KUL, Lublin 2007 